\title{
Sustainability of Urban Mobility of Campinas City, Brazil
}

\author{
Christian Turra ${ }^{1}$
}

\begin{abstract}
In the last decades, urbanization has increased and it has shown to be an irreversible process. The negative impacts of urban growth make to sustainable actions necessary. One of the cities that have national relevance in its economic, social and demographic aspects is Campinas, in the state of Sa o Paulo, Brazil. The objective of this study was to evaluate the performance of urban mobility and offer sustainable alternatives for the improvement of urban mobility in this city. A quali-quantitative survey was carried out with 234 citizens in Campinas, in three public squares and one municipal park. The results showed that the majority of the interviewed citizens were female, aged between 21 and 30 years old, undergraduate and employed with an income of 1 to 2 minimum wages. Their monthly expense on urban mobility represents, on average, $5 \%$ to $10 \%$ of the family income. The car was the main means of transportation. The main difficulty in transportation reported was traffic. Most of the interviewed individuals spend 10 to 20 minutes to commute to work or university. Among the main suggestions pointed out by the interviewees for the improvement of urban mobility are newer and more modern buses. Train or subway can be options to diminish the traffic and air pollution and were also suggested by the interviewees. Constant evaluation and monitoring of urban mobility are necessary to understand the real needs of the population and carry out the necessary actions.
\end{abstract}

Keywords: urban mobility; sustainability; Campinas city; vebicles, urban landscape.

\section{Introduction}

Cities create wealth, generate employment and urge human progress by harnessing the forces of agglomeration and industrialization (United Nations Human Settlements Programme, 2016). They are responsible for more than $70 \%$ of the global energy-related carbon dioxide emissions (World Resources Institute, 2014). In the last decades, there has been a significant increase in the urban population. In 1990, 43\% $(2.3$ billion) of the world population lived in urban areas; by 2015, this figure increased to 54 \% (4 billion) (United Nations Human Settlements Programme, 2016).

Mobility is almost universally acknowledged to be one of the most important prerequisites to achieve improved standards of living (World Business Council on Sustainable Development's, 2004).

Transportation is responsible for $23 \%$ of the global energy related to greenhouse gas emissions (International Energy Agency, 2015). Urban air pollution increases the cost of living and it can result in serious health problems such as respiratory diseases. Public transport is essential to reduce road congestion. It also creates value for individuals, 
businesses and public authorities by increasing the competitiveness of cities through economic strength, as well as allowing higher job density and productivity (United Nations, 2016).

It is clear that urban development and transportation are highly interdependent (CAETS, 2012). Mobility, especially in the form of motorized transport, requires an increasing share of land in cities and rural areas. An increase in the road area may reduce the quality of the urban environment, prevent people from walking and cycling, and cause changes in the households, forcing them to move (Petersen, 2004). The dense urban cores in many European, Japanese and Chinese cities, for example, enable residents to make from one third to two thirds of all their trips by walking and cycling (Rodrigue, 2017).

Some studies showed that there is a positive correlation between income and commuting time (Sermons and Koppelman, 2001; Manaugh et al., 2010). In Beijing, China, Zhao et al. (2011) found that commuting time of the low-income group is significantly longer than that of the high-income group.

The Goal 11 of the Sustainable Development Agenda of United Nations seeks to "make cities and human settlements inclusive, safe, resilient and sustainable". According to the European Comission (2013), the Sustainable Urban Mobility Plan has as its main goal the improvement of accessibility in urban areas and the provision of high-quality and sustainable mobility and transportation through and within the urban area. Thus, urban planning and design should focus on how to bring people and places together, by creating cities that focus on accessibility, rather than simply increasing the length of urban transport infrastructure or increasing the mobility of people. In Brazil, over $85 \%$ of the population live in urban areas, which is set to rise to $90 \%$ by 2050 , rendering cities a key opportunity for the reduction of greenhouse gases (World Resources Institute Brasil, 2017). The implementation and management of afforestation in cities constitute a public service, as a strategy of mitigation of adverse environmental impacts, due to the conditions of artificiality of the urban environment, as well as the ecology, history, culture, society, aesthetics and landscape, which influence people's feeling of comfort (Cemig, 2011).

One of the cities that have national relevance in its economic, social and demographic aspects is Campinas. It is considered the second most important city in the state of São Paulo, being one of the most important in Brazil. The city was founded in July of 1774. It has an international airport, several universities and research centers, privileged logistics localization, many high-technology companies, and leisure and tourism options. It has a population of 1,182,429 inhabitants, with demographic density of 1359.6 people $/ \mathrm{km}^{2}$ (IBGE, 2017), while its metropolitan region has 3,043,217 inhabitants or $1.5 \%$ of the Brazilian population. This region is constituted of 20 municipalities, being the tenth largest urban region in Brazil. The average monthly salary of formal jobs in this city is 4 minimum wages (data 2015), with Municipal Human Development Index (MHDI) of 0.805 (data 2010) (Atlas Brasil, 2013), while Human Development Index average in Brazil is 0.759 (United Nations Development Programme, 2018). The demographic density of the city of São Paulo, the largest city in Brazil, is 7,388 people $/ \mathrm{km}^{2}$ (IBGE, 2017). 
For a better understanding of the urban growth of Campinas in the last decades and its possible impacts on urban mobility, some relevant historical facts are shown in Table 1.

According to Bicalho and Rodrigues (2004), the beginning of public transportation in Campinas occurred in 1912, when the first electric trams began to circulate (Table 1). In the early 1930s, a bus line started operating, linking Campinas to Capivari. The last tram operated in 1968.

Light Rail Vehicle (LRV) operated in the city from 1990 to 1995. The system was deactivated due to the high cost of operation and corruption allegations (Silva, 2018).

During the decades of 60 and 70, there was a significant increase in the urban population in the city. From the 1970s, part of the population started living in slums, which grew rapidly (Baeninger, 1992). Slums or "favelas" are a physical and special manifestation of urban poverty and intra-city inequality (UN-HABITAT, 2003). The Brazilian Institute of Geography and Statistics (IBGE, 2011) defines favelas as "subnormal agglomerations" constituted of shacks/huts and houses, occupying or, until recently, occupied land that belong to others, either public or private, generally featuring a dense, disordered layout, the majority lacking essential public services.

From 1980 to 1996, the population of Campinas almost tripled, increasing from 376,000 to 909,000 people (Table 1).

The metropolitan region of the city has a car fleet of 2,2 million vehicles (Seade 2015), about 0.75 vehicles per inhabitant, while the city of Campinas, according to Denatran SP (2018), has a fleet of 916,682 vehicles (data December 2017), about 0.82 vehicles per inhabitant.

Table 1. Important historical facts of public transportation and urban growth of Campinas city

\begin{tabular}{ll}
\hline Year & Campinas historical facts \\
\hline 1912 & Beginning of public transportation (electric trams) \\
Decade 30 & First line of buses connecting Campinas to Capivari \\
1968 & The last tram to operate in the city \\
From 1960 to 1970 & Large urban growth \\
1970 s & Start of slums \\
1980 & Population 375,864 \\
1990 & Start of illegal transportation \\
From 1990 to 1995 & Light Rail Vehicle (LRV) \\
1996 & Population 908,906 \\
2000 & 454,490 vehicles \\
2017 & $1,182,429$ inhabitants x 916,682 vehicles \\
\hline
\end{tabular}

Sources: Baeninger (1992), Bicalho and Rodrigues (2004), Denatran SP (2018), IBGE (2017), Silva (2018).

Currently, there is a large concentration of favelas in the city. There are almost 150,000 people living in 40,000 households (IBGE, 2011). The rate of $12.9 \%$ is twice the national average and higher than the city of São Paulo (10\%). Almost 15,000 families $(36.5 \%)$ survive with a per capita income of half a minimum wage to one minimum wage and $61 \%$ of them never went to school or have incomplete elementary schooling (IBGE, 2011). The favelas are next to noble districts and scattered throughout the city (Diógenes, 2012). Favelas show the inequality in urban society. The Gini index in the city is 0.56 
(Atlas Brasil, 2013). This economic index is used to show income inequality. A society that scores 0.0 in the Gini scale has perfect equality in income distribution and a 1.0 score indicates total inequality. Campinas showed the highest value index in the metropolitan region, while Nova Odessa showed the lowest (0.41), i.e. the economic inequality in Campinas was the largest in the region.

The rate of urbanization in public roads is low, only 55.9\% (IBGE, 2017). This means that $44 \%$ of public roads do not have sidewalks, manholes or paving in proper conditions.

According to Bryan (2011), the city has an inefficient and obsolete public transportation system, practically unable to offer users the right of easy movement through the urban area, where they live with suitable quality, equity and security.

Urban growth was driven mainly by investments in industrial and research centers, improvement and expansion of roads, expansion works at Viracopos International Airport and large private constructions (shopping malls, condominiums, etc.), all linked to major real estate speculation. Effective and qualified public transportation has always been put aside (Fonseca, 2014). In a few years, the number of cars may exceed the number of inhabitants in the city and make the traffic and air pollution worse than it currently is (Table 1). Thus, sustainable actions are necessary to improve urban mobility in the city.

Sustainability consists of integrating and interrelating the economic, social, cultural and environmental aspects of a given sector. It is a dynamic and multidisciplinary process, which requires evaluation and constant monitoring. Ethic and transparency are important issues to the sustainability management system. Recycling (Turra, 2018) and certification process (Turra et al., 2014) for a specific sector may be important step that lead to sustainability although they are not enough to get it.

A sustainable urban mobility plan is a strategic plan built on existing planning practices and takes proper consideration of integration, participation and evaluation principles, in order to satisfy the mobility needs of people today and tomorrow, for a better quality of life in the cities and their surroundings (Rupprecht Consult, 2015).

One of the ten United Nation Organization's recommendations for the transportation sustainability is to "establish structures for monitoring and the evaluation of sustainable transport". In this approach, the objective of this study is to evaluate the performance of urban mobility and provide sustainable alternatives for the improvement of urban mobility in Campinas, in the state of São Paulo, Brazil.

\section{Methodology}

For the development of this study, a literature review was carried out, as well as a quali-quantitative survey with citizens of Campinas, in the state of São Paulo, Brazil, from March 2018 to April 2018. The research comprised about 2.2\% of Campinas city population or about 1\% (234 interviewed out of the 3 million people) of population in the Campinas metropolitan region. These people were interviewed in the entrance of 3 public squares (Bento Quirino, Largo do Carmo; Arautos da Paz, Vila Nogueira; Jardim Antonio Von Zuben, south region) and 1 municipal park (Parque Taquaral, Taquaral) in 
different regions of the city. These places were chosen because there is a social and economic diversity of the population.

The survey was conducted through a simple random sampling approach.

\section{Results and Discussion}

\subsection{Profile of the Interviewed Citizens}

Most of interviewed people were female (54\%), aged 21 to 30, with high school degree and employed (Table 2). It is necessary to consider that a part of the interviewed ones were young students and most of them will probably graduate.

Table 2. Profile of the interviewed participants

\begin{tabular}{llll}
\hline Age - years old & Gender & Education & Occupation \\
\hline $16-20(9.8 \%)$ & Female $(54 \%)$ & 1st grade $(11.5 \%)$ & Student $(19 \%)$ \\
$21-30(33.6 \%)$ & Male $(46 \%)$ & 2nd grade $(43.6 \%)$ & Employee $(53.9 \%)$ \\
$31-40(21.6 \%)$ & & Graduated $(34.7 \%)$ & Autonomous $(9.0 \%)$ \\
$41-50(17.3 \%)$ & & Post-graduated $(10.2 \%)$ & Unemployed $(8.1 \%)$ \\
$51-65(13.7 \%)$ & & Retired $(5.5 \%)$ \\
More than $66(4.0 \%)$ & & Entrepreneurs $(4.5 \%)$ \\
\hline
\end{tabular}

The majority of people with graduation are over 30 years old and employed. Most of the unemployed, not considering those who are studying, are aged 25 to 50 .

The range from 41 to over 65 years of age represents $35 \%$ of the interviewed. This group has the highest income among the interviewees and most of them are graduated (68\%). They use their cars mainly to get around and about $40 \%$ of them are willing to pay more for cleaner vehicles.

Concerning the employability, four of participants, answered they were unemployed, while fifteen of them, chose the option "others" in the questionnaire. Those fifteen, when asked to explain what was the other occupation, they confirmed to be unemployed (8.1\%) (Table 2). Around 9.0\% declared to be autonomous and 4.5\% entrepreneurs.

\subsection{Pollution and Traffic}

The results showed that Campinas' citizens are worried with air pollution and $31.5 \%$ of them are willing to pay more for vehicles that pollute less than the current ones (Table 3). Currently, most vehicles in the city run with gasoline, flex-fuel (ethanolgasoline) or diesel (buses, trucks and pickups). In Brazil, there are few options of hybrid and electric cars, which pollute less than the conventional ones (Natural Resources Canada, 2014). These cars represent less than $0.1 \%$ of the total vehicles. However, it is important to analyze whether the production and usage of an electric car is sustainable (lifetime emissions, commuting by car, spare parts, car insurance price, car price for purchase and resale, metals used, lifetime of batteries, recycling process).

Table 3. Campinas citizens are willing to pay more by vehicles more efficient and less pollution

\begin{tabular}{ccccc}
\hline Nothing & Up to $5 \%$ & Up to $10 \%$ & Up to $20 \%$ & Up to $30 \%$ \\
$68.5 \%$ & $23.5 \%$ & $5.9 \%$ & $1.28 \%$ & $0.85 \%$ \\
\hline
\end{tabular}


The trees are important to capture the atmospheric $\mathrm{CO}_{2}$, helping to mitigate the greenhouse effects. It is also important to improve urban landscape and to help create a better sense of well-being. The afforestation rate of public roads in the city is $87.5 \%$ (IBGE, 2017). It is a good value when compared to other big cities in Brazil, like Belém $(22.4 \%)$, in the state of Pará; Manaus (25.1\%), in the state of Amazonas; Rio de Janeiro (72.2\%), in the state of Rio de Janeiro; São Paulo $(75.4 \%)$, in the state of São Paulo; Porto Alegre (82.7\%), in the state of Rio Grande do Sul; but a low value in Goiânia $(89.5 \%)$, in the state of Goiás (IBGE, 2017).

Investing in reducing pollution and urban traffic may contribute with lower expenses for companies and municipalities. Thus, the money from this economy can be used to other areas as observed in Figure 1.

According to Toledo \& Nardocci (2011), studies showed a relation between air pollution in the city of São Paulo, Brazil, and respiratory and cardiovascular problems, fetal growth, increased mortality and hospitalizations, particularly in children and elderly people. The economic impact of health events associated with air pollution in 29 Brazilian metropolitan regions was evaluated (Miraglia \& Gouveia, 2014). The cost of premature deaths in Brazil was estimated in US\$1.7 billion annually.

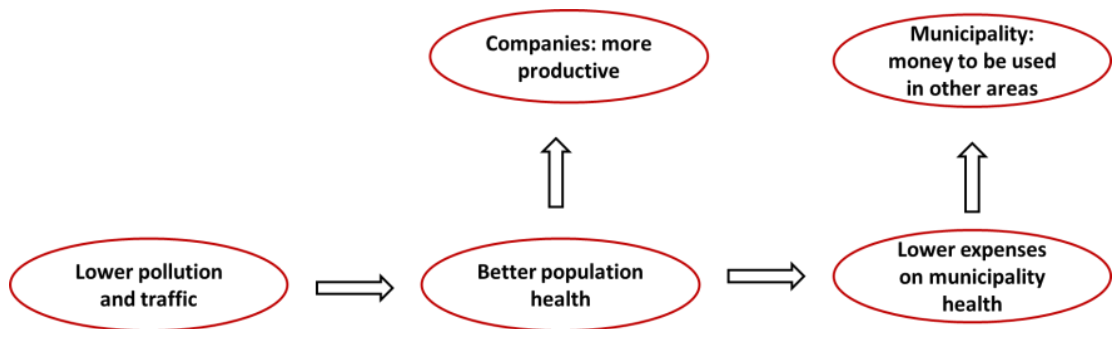

Figure 1. Main benefits in reducing pollution and urban traffic in cities.

\subsection{Income}

According to Table 4 almost half of interviewed citizens (49\%) has an income of 1 to 2 minimum wages (MW). The second group has 3 to $5 \mathrm{MW}(29 \%) ; 10 \%$ has 6 to 9 MW, the group of 10 to 12 MW has $7.3 \%$; and the last group (4.7\%) has an income higher than 12 MW. Currently, 1 minimum wage is $\mathrm{R} \$ 954,00$ per month or US $\$ 252.3$ (data May 2018) (1 dollar $=\mathrm{R} \$ 3,7811)$ (Infomoney, 2018).

Table 4. Campinas citizen`s income in minimum wages (MW)

\begin{tabular}{ccccc}
\hline 1 to $2 \mathrm{MW}$ & 3 to $5 \mathrm{MW}$ & 6 to $9 \mathrm{MW}$ & 10 to $12 \mathrm{MW}$ & higher than $12 \mathrm{MW}$ \\
$49 \%$ & $29 \%$ & $10 \%$ & $7.3 \%$ & $4.7 \%$ \\
\hline
\end{tabular}

\subsection{Urban Mobility}

The car is the main type of urban transportation for $38.9 \%$ of the interview participants. People who only use buses represent $32 \%$ of those interviewed, followed by people who move around on foot $(4.7 \%)$, by bicycle $(4.3 \%)$, by motorcycle $(3.9 \%)$, by taxi or Uber (3\%) and school bus (2.1\%). Other $8.6 \%$ use both car and bus; while $2.5 \%$ use both car and bicycle. 
The monthly expenditure on urban relative mobility represents on average $5 \%$ to $10 \%$ of the family income from $35.9 \%$ of the interviewed, followed by people who spend over $5 \%$ (34.6\%). The expenditure range from $10 \%$ to $20 \%$ represents $19.2 \%$ of the interviewed ones. Almost $6 \%$ of them have an expenditure range of $20 \%$ to $30 \%$, and $1.8 \%$ have an expenditure range of $30 \%$ to $50 \%$. Almost $4 \%$ of the interviewed citizens said they could not afford to pay for urban mobility and they depend on the help of others.

Currently, the single bus ticket costs $\mathrm{R} \$ 4.30$ (most of the users use single bus ticket). With this ticket, it is possible to make up to three uses in a two-hour period, from Monday to Monday. The first integration of the single free ticket and the vouchertransport is free. In the second integration, the user needs to pay $\mathrm{R} \$ 0.40$ (Emdec, 2018). Thus, if a person works 21 days per month and uses 2 single bus tickets per day, one`s monthly expenditure is $\mathrm{R} \$ 180.60$, which corresponds to $19 \%$ of the minimum wage (MW).

Most interviewed citizens $(65 \%)$ do not have problems with locomotion in the city. However, 35\% of the interviewed citizens reported difficulties. The main issues reported were traffic (mainly by car drivers) (28\%), old buses $(19 \%)$, disrespect $(9 \%)$, harassment on buses reported by women $(8 \%)$, lack of punctuality by buses $(6.7 \%)$, bad streets and sidewalks (4\%), impolite bus drivers (2.8\%) and lack of respect for the elderly $(1.8 \%)$.

Poor conditions of public roads damage the traffic and public transportation as a whole, as well as the living standards of the population.

Most of the interviewed $(36 \%)$ spend 10 to 20 minutes going from home to work. The journey from 20 to 30 minutes represents $16 \%$ of the interviewed. Twelve percent spend 10 minutes maximum. However, $8 \%$ spend from 1 hour to 1 hour and 50 minutes. Most of the people who use buses to move around spend on average $58 \pm 41$ minutes in their journey, whereas people who use cars spend on average $46 \pm 35$ minutes. Most of the people who use bicycle or walk spend up to 10 minutes to commute. If there is a safe system with infrastructure for bicycles, it may encourage other people to use them, too (Wang et al., 2015).

An international survey with 74 cities around the world about public transportation, Rio de Janeiro metropolitan region in Brazil was the worst city for commuting, while Campinas metropolitan region was the 61st worst city (Julliard, 2018).

Among the main suggestions pointed out by interviewees for the improvement of urban mobility are newer and modern buses $(29 \%)$, put in operation lines of trains or subway $(27 \%)$, covered bus stops $(21 \%)$, new cycle lanes $(8 \%)$, new bus lanes $(3.5 \%)$.

According to Miranda (2010), Curitiba, in the state of Paraná, Brazil, is considered a reference for good urban planning and transportation practices. The urban mobility is characterized by the efficiency and comprehensiveness of public transportation. However, there are limitations such as the population's dependence on motorized vehicles, reduced use of the bicycle by the population as a regular mean of transport; reduced number of footpaths that are exclusive for pedestrians. Campinas has the same limitations. The city has 120 kilometers of railway beds within the municipality that can be used. 
Currently, there are some actions to improve urban mobility in the city. There is a study to put in operation a link from the city center to Viracopos airport, the first in an urban rail network in Campinas (Correio Popular, 2017). Campinas delivered $15 \mathrm{~km}$ of bike paths between 2013 and 2017 (G1 Campinas e Região, 2018).

An option to improve local sustainability where everyone can benefit is to promote actions with private and public companies in order to encourage the use of solar energy in the buildings, allowing solar power to gain more mainstream acceptance. Solar energy has great potential in Brazil, since the country has one of the highest levels of insolation in the world (Martins, 2007) and the price of solar panels has decreased in the last 5 years (Pereira, 2017). There are financing conditions for projects of electric power generation by public and private banks. Solar energy can be used not only for main activities of companies, but also for hybrid or electrics vehicles (automobiles and buses). The use of this clean energy, if carried out effectively, can contribute to the companies' image (concerned with the well-being of population and with the environment), as well as the local environment, by reducing air pollution, and the national environment, contributing to a lower dependence of hydro and thermal energy.

\section{Conclusions}

All interviewees are concerned with the environmental pollution in the city and about $30 \%$ of them are willing to pay more for vehicles that pollute less. The use of trains or subway can be options to diminish the traffic and air pollution.

In order to allow the present and future generations to have a satisfactory urban mobility, some actions are necessary, such as:

- improve conditions of the public roads;

- the gradual exchange for less polluting vehicles for a better air quality;

- plan for a gradual change in the energy matrix, which will demand a greater amount of electric energy;

- integrate transportation systems - vehicles, bicycling, and walking - so that the mobility is as fast, efficient, safe and affordable as possible;

- a sustainable management with evaluation and constant monitoring of urban mobility to understand the real needs of the population and carry out the necessary actions.

\section{References}

Atlas Brasil (2013). Perfil - Campinas, SP / Atlas do desenvolvimento bumano no Brasil. Retrieved from http://www.atlasbrasil.org.br/2013/pt/perfil_m/campinas_sp.

Baeninger, R. A. (1992). Espaço e tempo em Campinas: migrantes e a expansão do polo industrial paulista. [212] f. Dissertação (mestrado) - Universidade Estadual de Campinas, Instituto de Filosofia e Ciências Humanas, Campinas, SP. Retrieved from http://libdigi.unicamp.br/document/?code $=000042230$.

Bicalho, M. P., \& Rodrigues, M. (2004). Trilhos e Linhas: História do transporte coletivo de Campinas. Campinas, Prefeitura Municipal de Campinas/EMDEC.

Bryan, F. (2011) Mobilidade urbana em Campinas = análise do espaço de circulação. 155 p. Dissertação (mestrado) Universidade Estadual de Campinas, Instituto de Geociências, Campinas, SP. Retrieved from http://www.bibliotecadigital.unicamp.br/document/?code $=000804320 \&$ opt $=1$

CAETS (2012). A Statement by the International Council of Academies of Engineering and Technological Sciences. Urban Development and Public Transportation: Improved Understanding of the Interdependencies. 
Cemig - Companhia Energética de Minas Gerais (2011). Manual de arborização. Belo Horizonte: Cemig / Fundação Biodiversitas. 112 p.

Correio Popular (2017). Campinas volta a avaliar transporte sobre trilhos. Retrieved from http://correio.rac.com.br/_conteudo/2017/03/campinas_e_rmc/474722-campinas-volta-aavaliar-transporte-sobre-trilhos.html

Denatran (2018). Frota de veículos. Retrieved from https://www.denatran.gov.br/frota.htm

Emdec (2018). Sistema de Transporte Público de Campinas (SISTEMA INTERCAMP) Retrieved from http://www.emdec.com.br/eficiente/sites/portalemdec/pt-br/site.php?secao=tarifas

European Comission (2013). A concept for sustainable urban mobility plans. Annex. Brussels. 5p.

Fonseca, H. R. (2014). O recente processo de urbanização da cidade de Campinas-SP (1990-2014): as ocupacões urbanas um estudo dos usos do território da Região Sul. Dissertação (mestrado) - Universidade Estadual de Campinas, Instituto de Geociências.

G1 Campinas e Região (2018). Após descumprir meta de $122 \mathrm{~km}$ em ciclovias, Campinas negocia empréstimo de R\$50 milhöes para acelerar obras. Retrieved from https://g1.globo.com/sp/campinas-regiao/noticia/aposdescumprir-meta-de-122-km-em-ciclovias-campinas-negocia-emprestimo-de-r-50-milhoes-paraacelerar-obras.ghtml

Infomoney (2018). Dólar hoje. Retrieved from https://www.infomoney.com.br/dolar

International Energy Agency (2015). $\mathrm{CO}_{2}$ Emissions From Fuel Combustion - Highlights Retrieved from https://www.iea.org/publications/freepublications/publication/CO2

EmissionsFromFuelCombustionHighlights2015.pdf

Instituto Brasileiro de Geografia e Estatística - IBGE (2011). Censo demográfico 2010. Aglomerados subnormais. Rio de Janeiro: IBGE.

Instituto Brasileiro de Geografia e Estatística - IBGE (2017). Panorama dos municípios brasileiros. Retrieved from https://cidades.ibge.gov.br/brasil

Julliard, S. (2018). The best and worst cities for commuting. Retrieved from https://www.expertmarket.co.uk

Manaugh, K., Miranda-Moreno, L. F., \& El-Geneidy A. M. (2010). The effect of neighborhood characteristics, accessibility, home-work location, and demographics on commuting distances. Transportation, 37(4), 627-646.

Martins, F. R., Pereira, E. B., de Abreu, S. L., \& Colle, S. (2007). Brazilian Atlas for Solar Energy Resource: Swera Results $2007 . \quad$ Retrieved from http://www.lepten.ufsc.br/publicacoes/solar/eventos/2007/ISES/martins_enio.pdf

Miranda, H. F. (2010). Mobilidade urbana sustentável e o caso de Curitiba. Dissertação. Escola de Engenharia de São Carlos, Universidade de São Paulo.

Miraglia, S. G. El K., \& Gouveia N. (2014) Costs of air pollution in Brazilian metropolitan regions. Ciência Saúde Coletiva, 19(10), 4141-4147.

Natural Resources Canada (2014). Learn the facts: fuel consumption and $\mathrm{CO}_{2}$. Retrieved from http://www.nrcan.gc.ca/sites/www.nrcan.gc.ca/files/oee/pdf/transportation/fuel-efficienttechnologies/autosmart_factsheet_6_e.pdf

Pereira, E. B. (2017). Overview of Solar Energy in Brazil. Retrieved from http://www.fapesp.br/eventos/2017/11339/9h30_Enio-Bueno.pdf

Petersen, R. (2004). Land Use Planning and Urban Transport. 48 p. Retrieved from https://www.sutp.org/files/contents/documents/resources/A_Sourcebook/SB2_Land-Use-

Planning-and-Demand-Management/GIZ_SUTP_SB2a-Land-use-Planning-and-UrbanTransport_EN.pdf

Rodrigue, J. P. (2017). The geography of transport systems. New York: Routledge, 440 pages. ISBN 978113866957424.

Rupprecht Consult (2015). Sustainable Urban Mobility Plan. Retrieved from http://www.rupprechtconsult.eu/uploads/tx_rupprecht/SUMP_Brochure_final.pdf

Seade (2015). Radar Seade. A frota de veículos no estado de São Paulo. Retrieved from https://www.seade.gov.br/produtos/midia/radar/radar_seade_n4.pdf

Sermons, M. W., \& Koppelman, F. S. (2001). Representing the differences between female and male commute behavior in residential location choice models. Journal of Transport Geography, 9, 101-110.

Silva, T. (2018). VLT de Campinas: uma boa ideia pouco aproveitada. Retrieved from https://plamurbblog.wordpress.com/2018/01/30/vlt-de-campinas-uma-boa-ideia-poucoaproveitada/ 
Toledo, G. I. F. M., \& Nardocci, A. C. (2011) Traffic related air pollution and population health: a review about São Paulo (SP), Brazil. Revista Brasileira de Epidemiologia, 14(3): 445-454.

Turra, C., Vian, C. E. F., Nielsen, F. A. G., Santos, P. S., \& Penteado, L. F. F. (2014). Overview of the Brazilian citriculture certification. Journal of Agricultural Environmental Ethics, 27: 663-679.

Turra, C. (2018) Sustainability of rare earth elements chain: from production to food - a review. International Journal of Environmental Health Research, 28(1): 23-42.

UN-HABITAT (2003). The Challenge of Slums: Global Report on Human Settlements. ISBN: 978-1-84407-037-4, 345 p. Retrieved from https://unhabitat.org/books/the-challenge-of-slums-global-report-onhuman-settlements-2003/

UN-HABITAT (2013). Global Report on Human Settlements. ISBN: 978-92-1-132568-3. 348 p.

United Nations Human Settlements Programme (2016). Urbanization and Development: Emerging Futures. World Cities Report 2016. 248 p. Retrieved from https://www.unhabitat.org

United Nations (2016). Mobilizing Sustainable Transport for Development. Retrieved from https://sustainabledevelopment.un.org/content/documents/2375Mobilizing $\% 20$ Sustainable $\% 20$ Transport.pdf

United Nations Development Programme (2018). Human Development Reports. Brazil. Retrieved from http://hdr.undp.org/en/countries/profiles/BRA

Wang, C -H., Akar, G., \& Guldmann, J -M. (2015). Do your neighbors effect your bicycling choice? A spatial probity model for bicycling to the Ohio State University. Journal of Transport Geography, 42.

World Business Council on Sustainable Development's (2004). Mobility 2030: Meeting the challenges to sustainability. The Sustainable Mobility Project. 180p.

World Resources Institute (WRI) (2014). Global Protocol for Community-Scale Greenhouse Gas Emission Inventories. 176 p. Retrieved from https://ghgprotocol.org/sites/default/files/standards/GHGP_GPC_0.pdf

World Resources Institute (WRI) Brasil (2017). GHG protocol for cities. Retrieved from https://wribrasil.org.br/en/our-work/projects/ghg-protocol-cities

Zhao, P. J., Lü, B., \& de Roo, G. (2011). Impact of the Jobs-Housing Balance on Urban Commuting in Beijing in the Transformation Era. Journal of Transport Geography, 19(1): 59-69. 